\title{
1_jurnal_JIT_APR_2009.pdf
}

Submission date: 22-May-2019 03:46AM (UTC+0700)

Submission ID: 1134041555

File name:1_jurnal_JIT_APR_2009.pdf (5.02M)

Word count: 5106

Character count: 33194 


\title{
HAMBATAN EKONOMI INDONESIA TERHADAP PEREKONOMIAN GLOBAL
}

\section{Agussalim M.}

\begin{abstract}
Abstrak
Pemeratan kesempatan berusaha di Indonesia masih banyak menghadapi kendala yang bersifat struktural. Kendala-kendala tersebut sulit ditembus khusunya oleh para pelaku ekonomi kuat masuk pasar dan memperkuat penghalang masuk dengan mengadakan berbagai konglomerasi bisnis yang seharusnya dapat dilakukan oleh para pelaku ekonomi kecil dalam skala kecil-kecilan. Rendahnya kesempatan berusaha ini juga akbiat dari tidak seragamnya aliran masuk modal antara pelaku ekonomi kuat dan ekonomi kecil. Modal sangat santer mengalir ke pelaku ekonomi kuat, sehingga pelaku ekonomi kecil terhambat masuk ke industri yang bersifat kompetetif.

Kata kunci : hambatan, ekonomi Indonesia, perekonomian global
\end{abstract}

\section{PENDAHULUAN}

Pemasaran komoditas ekspor non migas masih banyak menghadapi kendala menjelang era tinggal landas sekarang ini. Kendala tersebut disamping berasal dari faktor-faktor internal dalam negeri, juga berasal dari faktor eksternal luar negeri. Makalah ini bermaksud membahas hambatan ekspor non migas yang berasal dari faktor eksternal, yaitu berupa hambatan tarif dan non tarif yang dikenakan oleh tujuan ekspor terhadap komoditas ekspor non migas Indonesia.

Pemerataan kesempatan berusaha merupakan tujuan yang di amanatkan UndangUndang Dasar 1945. Pelaksanaan pemeratan berusaha ini dirasakan masih banyak menghadapi kendala terutama bersifat stuktural di indonesia. Makalah ini berupaya mengetengahkan beberapa kendala stuktural yang terjadi khususnya pada pelaku ekonomi kecil. 


\section{Struktur Sektor Pertanian vs Industri}

Sektor pertanian di Indonesia, khususnya pertanian tanaman pangan, memiliki struktur pasar yang kompetitf dan menyebar diseluruh pelosok tanah air. Misalnya, tanaman padi ditanami oleh petani yang ada di Indonesia. Hal ini membawa dampak positif berupa relatif stabilnya keamanan pangan, apalagi setelah Indonesia mencapai swasembada pangan, khususnya beras. Namun kondisi initidak membawa pertumbuhan yang berarti pada sektor berintegratif rendah telah menurunkan kondisi struktur input yang berkualitas rendah pula.

Struktur permintaan tenaga kerja, modal, tanah dan kewiraswastaan sangat tergantung pada strukturpermintaan output yang sepenuhnya ditentukan olehmekanisme pasar. Kondisi struktur output sektor pertanian dapat dilihat pada aspek keterkaitan antar produk yang dikelompokan ke dalam terkaitan positif (subtitusi),negatif (komplemen), dan tanpa kaitan (bebas). Keterkaitan intrasektor boleh dikatakan rendah,karena kenaikan harga suatu komidas pertanian yang lain. Hal ini disebabkan oleh rendahnya diversifikasi konsumsi pada masyarakat kita akibat dari sedikitnya pilihan konsumsi terutama di luar jawa dan loyalitas konsumsi pada satu komidas primer, khususnya di jawa.

Keterkaitan antar sub sektor juga belum terlihat nyata karena perbedaan karakteristik antara sub setor tanaman pangan, perkebunan, kehutanan, dan perikanan. Sementara itu keterkaitan antar sektor, khususnya antar sektor pertanian dan sektor industri belum berkembang sebagaimana yang diharapkan. Sementara itu struktur output sektor industri telah berkembang pesat dalam berbagai konglomerasi yang bersifat vertikal (dari industri hulu sampai hilir), horisontal (antar perusahaan dan antardaerah), serta konglemerasi murni (antara industri yang tidak berkaitan). Hubungan antar output juga berkembang pesat baik hubungan substitusi maupun komplementer. Hal ini satu sama lain menyebabkan nilai tambah di sektor industri berkembang, melebihi sektor pertanian. Disamping itu kondisi pasar output yang kebanyakan bersifat monopolistik di sektor industri telah menyebabkan kepercayaan bank terhadap pengusaha di sektor industri lebih mantap di banding kepercayaannya pada petani, peternak, dan nelayan.

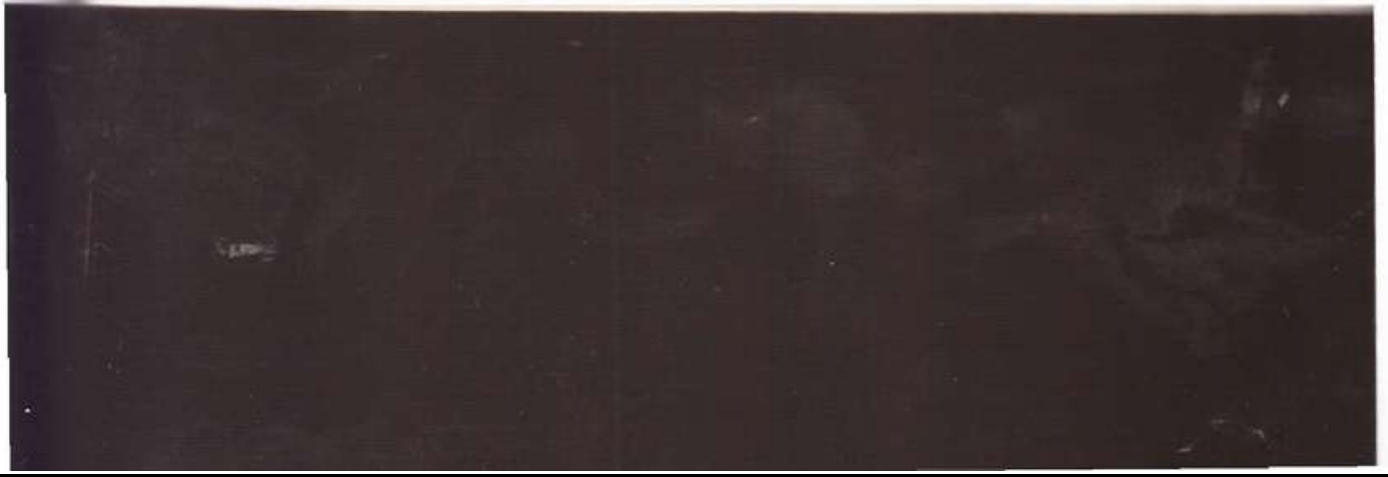


Hal ini yang membuat sektor industri relatif tidak memiliki kendala dalam hal permodalan.

Keterpisahan perlakuan terhadap sektor pertanian lebih diprioritaskan dibanding sektor industri, maka dalam kebanyakan hal tersebut hanya benar untuk sebagian. Hal ini terlihat dari porsi kredit yang mengalir ke sektor industri. Disamping hal tersebut, keterkaitan antar sektor industri dan pertanian dalam agro-industri juga relatif belum berkembang lainya.

Perbedaan karakteristik pasar kedua sektor tersebut, yaitu dominasi pasar monopolistik di sektor industri dan pasar kompetatif di sektor pertanian telah menyebabkan perbedaan pertumbuhan dan pangsa pasar kedua sektor tersebut dalam "perekonomian nasional. Secara teoritis memang dibenarkan bahwa pangsa pasar sektor pertanian akan terus menerun sementara pang pasar sektor industri dalam PDRB terus meningkat, namun pembenaran tersebut terlalu cepat terjadi di Indonesia.

Apabila sektor pertanian yang bergabung dalam lima sub sektor benar-benar diperlukan istemewa repelita, maka kemungkinan daya tahan sektor ini pada saat tinggal landas nanti akan dapat lebih dibanggakan. Hal ini ibarat perlakuan antara dua anak berbeda kemampuan dalam sebuah keluarga. Anak yang lemah harus lebih diperhatikan dibandingkan anak yang pandai agar keduanya dapat berkompetisi secara adil dan beradab. Bila kondisi sektor pertanian yang lemah tidak didukung oleh inventasi besarbesaran sebagaimana yang terjadi di sektor industri dan keterkaitan antara kedua sektor tersebut lemah, maka dikhawatirkan terjadi dualisme sektor yang mengarah pada ketidakadilan ekonomi di Indonesia.

\section{Hambatan Tarif dan Non-Tarif}

Hambatan tarif masih banyak dilakukan oleh negara-negara tujuan ekspor untuk melindungi komiditas sejenis yang diproduksi negara tersebut secara kurang efisien. Hambatan tarif ini berupa tarif per unit yang di kenakan sebesar rupiah tertentu per unit barang dan tarif ad valorem yang dikenakan sebesar presentase tertentu dari unitbarang impor. Kedua macam tarif ini biasanya dikenakan kepada komoditas ekspor non-migas kita. Amerika Serikat telah lama memakai kedua jenis tarif ini terhadap negara-negara mitra dagangnya. Negara-negara tersebut oleh pihak AS dikategorikan kedalam tiga 
macam, yaitu negara-negara dengan perlakuan khusus, antara lain yang termasuk dalam penanda tanganan referensi sistem umum(GPS), dikenakan tarif ad valorem sebesar 0 persen atau dibebaskan dari tarif. Negara-negara sahabat dekat yang telah makmur dikenakan tarif bervariasi antara 5 - 5 persen, sedangkan negara-negara komunis dan bukan sahabat, dikenakan tarif lebih tinggi, yaitu sekitar dua kali lipat dari yang dikenakan terhadap negara-negara kapitalis lainya.

Hambatan non tarif banyak dilakukan negara industri maju sebagai ganti dari kebijakan penghambat tarif. Hambatan bukan tarif biasanya dilakukan terhadap komoditas impor yang berharga relatif lebih murah dibandingkan harga komoditas sejenis di dalam negeri. Dengan demikian, hanya komoditas relatif mahal yang tidak efisien yang dapat masuk negera industri maju tanpa dikenakan penghalang masuk non tarif. Hal ini menyebabkan para eksportir dengan kemampuan menawar terendah dirugikan.

Gejala meningkatnya penghalang non tarif pada dekade 1980-an masih sulit diungkap secara kuantitaf karena sulit mengukur dampaknya terhadap kesejahteraan masyarakat dan perdagangan secara umum. Penghalang non tarif ini dianggap tidak adil karena para ekportir diperlakukan tidak sama. Misalnya, Hong Kong dan Korea Selatan justru mengalami kesulitan dalam mengendalikan ekspornya, meskipun perlakuan tarif cukup menguntungkan.

Dilihat dari kepentingan konsumen, maka penghalang bukan tarif ini jelas merugikan,karena mendorong konsumen negara mengimpor untuk membayar lebih tinggi. Di samping itu,penghalang non tarif menyebabkan negara pengimpor kehilangan penghasilan dari tarif. Pada giliranya hal ini menyebabkan alokasi sumberdaya menjadi kurang efisien dan etika persaingan bebas menjadi luntur.

Ketika perjanjian baru tentang negosiasi perdagangan multilateral ditandatangani di Quinta Del Este (Uruguay, 1986), maka negara-negara penandatangan setuju untuk memantapkan liberlisasi perdagangan internasional dengan memberi kemudahan pada impor dan memperkuat kompetisi ekspor. Tiga butir perjanjian Uruguay dapat disebutkan sebagai berikut : memperbaiki kondisi pasar melalui pengurangan terhadap barrier 
import, meningkatkan disiplin pengunaan berbagai subsidi langsung dan tidak langsung, serta meminimalkan pengaruh balik dari kebijakan yang tidak sehat.

Beberapa pendekatan telah mengmunkinkan untuk mencapai tujuan di atas, meskipun satu sama lain masih memiliki kelemahan. Misalnya:beberapa negara dapat melakukan negosiasi tarif dan non tarif atas dasar tawar menawar; beberapa negara dapat membatasi kebijakan perdagangannya dengan mengurangi subsidi impor; beberapa negara dapat mengadakan negoisasi penggunaan berbagai tipe instrumen kebijakan termasuk kebijakan barier non tarif; Beberapa negara dapat mengurangi semua barrier non tarif dan membuat penyesuain untuk mencapai kesepakatan; dan beberapanegara dapat pula membebaskan tingkat bantuan terhadap produsen suatu komoditas tertentu.

Pada masa lalu, hanya data tentang tarif yang dapat dianalisis sebagai alat kebijakan pemerintah. Barrier non tarif sebagai bersifat deskriptif sehingga sulit diperbandingkan pengaruhnya terhadap tarif. Sebuah analisis equivalen tarif terhadap bentuk-bentuk non tarif telah disepakati dan berhasil dilakukan di negara-negara maju, yaitu konsep akuivalen subsidi produsen atau konsumen.

Selama ini komoditas non migas lebih banyak tergantung pada permintaan dalam negri. Usaha-usaha untuk mengembangkan potensi komoditas non migas mulai dilancarkan sejak penerima negara dari ekspor merosot akibat penurunan harga minyak sejak tahun 1980-an. Untuk mengetahui dan menggalakkan ekspor komoditas non migas dibutuhkan analisis pasar dan potensi pasar di luar negeri pada dasarnya merupakan usaha yang tidakmudah, karena itu studi yang mendalam tentang kelayakan usaha peningkatan ekspor untuk beberapa komoditas perlu dilakukan.

Indonesia sebagai salah satu pengekspor komoditas non migas terbesar di dunia perlu menggali potensinya lebih lanjut dalam meningkatkan potensi permintaan pasar luar negeri. Usaha ini dapat dilakukan dengan meneliti potensi-potensi di berbagai daerah untuk beberapa komoditas yang memiliki daya saing dengan komoditas sejenis di luar negeri. 
Agenda penelitian dengan demikian perlu di susun untuk:

1. Mengetahui penawaran dan permintaan beberapa komoditas pertanian di pasar domestik dan luar negri.

2. Mengali peluang-peluang pasar luar negri untukk beberapa komoditas non migas dari Indonesia

3. Mencari strategi pemasaran yang cocok untuk dapat diterapkan di pasar internasional.

Beberapa langkah penelitian dapat digambarkan sebagai berikut.

1. Menganalisis fakta-fakta ekonomi pasar dalam kaitannya dengan perkembangan output, harga, teknologi, kondisi alam, dan resiko harga.

2. Menganalisis kondisi produksi, distribusi,dan pasar beberapa komoditas non migas di pasar lokal dan internasional.

3. Menganalisasi permintaan aktual dan potensial bagi beberapa komoditas non migas di pasar internasional.

Kebijakan pemerintah sangat berperan dalam pengmbangan komoditas non migas dimasa mendatang. Beberapa komoditas non migas yaitu komoditas yang mempunyai potensi pasar di luar negri antara lain;barang-barang kerajinan seperti rotan; komoditi pertanian seperti teh, kopi, palawijaya; komoditi industri seperti textil.

Campur tangan pemerintah dalam perdagangan internasional dapat dilakukan melalui kebijakan tarif dan non tarif. Kebijakan tarif sudah banyak dibahas sehingga tidak perlu dibahas lebih lanjut dalam tulisan ini. Kebijakan non tarif masih relatif baru dan mulai mendapat perhatian baik melalui forum nasional maupun internasional. Studi ini akan meneliti pengaruh non tarif terhadap kesejahteraan produsen dan konsumen di indonesia lewat ukuran yang dikenal sebagai Producen Subsidy Equivalent (PSE) dan Consumer Subsidy Equivalent (CES).

Pendekatan PSE dan CSE dikembangkan oleh Josling (1981) dalam menganalisi intervensi pemerintah di sektor pertanian. Metode ini kemudian dikembangkan dalam 
studi-studi yang dilakukan oleh negara-negara yang bergabung dalam OECD. Pendekatan Josling ini pada dasarnya mengukur kebijakan pemerintah dalam :

1. Tingkat subsidi yang diperlukan untuk memberi kompensasi kepada produsen akibat perubahan kebijakan pemerintah.

2. Tingkat subsidi yang seharusnya dibayar kepada konsumen sebagai akibat berubahnya kebijakan pemerintah.

Gabungan antara kedua hal ini menunjukan transfer bersih dari lain sektor melalui pemerintah kepada sektor yang diteliti.

Pendekatan PSE pada dasarnya merupakan gabungan berbagai pengaruh kebijakan pemerintah. Komponen PSE dapat diturunkan lewat dua cara. Pertama, dengan melihat pengaruh budgetari dari kebijakan pemerintah, dan kedua, dengan melihat pengaruh instrumen kebijakan terhadap selisih harga-harga domestik dan internasional.

PSE dan CSE didasarkan pada data harga-harga produksi, konsumsi, dan perdagangan pada kondisi kebijakan yang berlaku. Kegunaan kedua konsep ini adalah untuk membandingkan relatif pentingnya kebijakan pemerintah pada berbagai negara dan komoditas yang berbeda dalam kaitanya dengan kontribusi penghasilan produsen dan biaya konsumen. Perubahan dalamPSE dan CSE dapat disebabkan oleh perubahan kebijakan pemerintah atau perubahan tingkat harga internasional atau nilai tukarnya.

Kategori kebijakan non tarif, yaitu:kebijakan penentuan harga pasar, terdiri dari dorongan harga domestik, pajak ekspor, sistem dua harga, pemberian kredit komoditas, kebijakan-kebijakan ini telah banyak dilakukan oleh pemerintah kita, Namun begitu efektivitasnya lebih banyak dinikmati oleh para produsen saja. Beberapa komoditas yang mempunyai elastisitas penawaran inelastik, pemberian kredit ekspor bahwa kurang berpengaruh terhadap tambahan surplus produsen.

Kebijakan mendorong pendapatan langsung, meliputi : pembiayaan langsung dan pajak produsen. Disamping itu program mengurangi biaya produksi, meliputi subsidi : subsidi pupuk, pengecualian pajak bahan bakar, subsidi teknis dapat terus dilanjutkan sejauh kesejahteraan produsen merupakan titik berat perekasayaan ekspor non migas

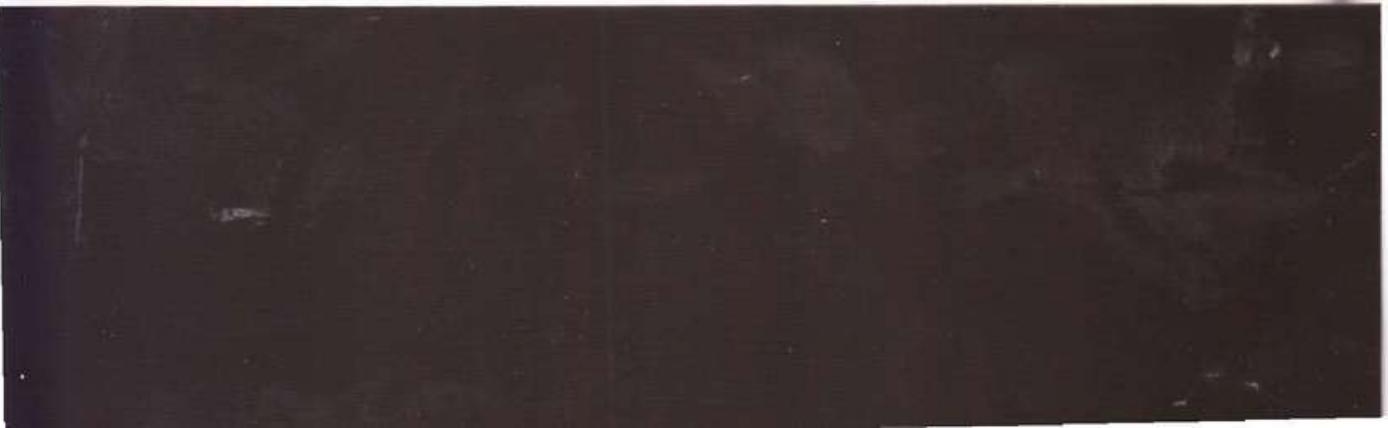


kita. Namun bila rekayasa pemasaran lebih diutamakan, maka program mengurangi biaya pemasaran,meliputi subsidi angkutan, program promosi dan pemasaran, serta pelayan pengawasan justru yang harus diproritaskan. Tampaknya dalam waktu mendatang yang dekat ini pendekatan pemasaran harus di utamakan, karena pada masa ini sektor pemasaran komoditas non migas Indonesia paling banyak memiliki titik lemah dibanding negara kompetetif kita seperti Thailand dan Malaysia.

Program meningkatkan produksi jangka panjang sudah harus dipikirkan bagi pengembangan ekspor non migas kita terutama dalam menghadapi era tinggal landas dan sesudahnya. Program ini meliputi:pelayanan penelitian dan penyuluhan bagi para eksportir dan calon eksportir yang berminat. Program jangka panjang ini juga perlu dilengkapi dengan program pelengkap, seperti program konservasi lingkungan programprogram struktural, dan terakhir program pengawasan nilai tukar, meliputi : pengawasan tetap, pengawasan mengambang, dan pengawasan terkendali.

Program-program diatas perlu dipersiapkan dengan mengadakan perubahan struktur ekonomi yang membawa dampak terhadap aktivitas masyarakat. Struktur sektor pangan baik vertikal maupun horizontal pada berbagai tingkat dari petani konsumen akhir sangat dipengaruhi oleh tipe organisasi dalam memperoleh manfaat ekonomidalam anggotanya. Karena integrasi masyarakat sangat cocok diterapkan dalam struktur industri. Misalnya KUD terlibat dalam berbagai tahap sistem pemasaran pangan dan pengolahan, transportasi, sampai ke ekspor. Koperasi jasa dapat menjebatani kepentinggan produsen, pengelolah, dan pedagang besar lewat intergrasi vertikal. Integrasi vertikal ini berupa: memperoleh untung pada setiap tingkat pasar; memotong struktur pasar yang menguntungkan; memperoleh manfaat skala ekonomis; dan meningkatkan efisiensi dari koordinasi vertikal.

Sektor pangan di tingkat ekspor pada umumnya ditangani oleh segelintir produsan konglomerat dimana kebanyakan mengkoordinir aktivitasnya secara intergral dalam suatu aktivitas industri penggolahan dan tranportasi komoditas. Mereka cenderung berspekulasi pembelian demikian membutuhkan peranan masyarakat dan asosiasi 
dagang untuk membentuk pasar baru dengan harga yang lebih kompetitif. Karakteristik komoditas dan perpencaran sumberdaya ikut mendukung meningkatnya peranan masyarakat di sektor ini.

\section{Pemerataan Kesempatan Berusaha}

Bicara mengenai anatomi pengusaha pengusaha ekonomi kecil dapat digolongan ke dalam pelakunya di pasar input dan pasar output. Dari kedua pasar ini akan diketahui bahwa kedudukan mereka lemah secara struktural, karena itu usaha-usaha ke arah perbaikan nasib pengusaha ekonomi kecil hanya dapat dilakukan secara struktural dan berjangka penjang.

Di pasar input, pengusaha ekonomi kecil hanya bisa menjual jasa dalam bentuk tenaga kerja saja. Mereka tidak memiliki input lain seperti modal, lahan pertanian yang cukup, dan tingkat kewiraswastaan yang mantap. Tenaga kerja yang dapat mereka sediakanpun sangat homogen dan berjumlah tak terbatas (un-limited labour supply), sehingga upah yang dapat mereka harapkan hanya sebatas pada kebutuhan konsumsi minimal untuk dua orang. Bila jumlah anggota keluarga empat, maka suami istri harus bekerja untuk bisa menutup kebutuhan konsumsi sekeluarga.

Kondisi struktural pasar tenaga kerja, baik informal maupun formal, pada dasarnya tidak jauh berbeda. Di pasar informal pengusaha ekonomi kecil yang tergolong dalam pelaku ekonomi lemah berharap dengan urusan usaha yang relatif sangat kecil, sehingga tidak memiliki daya saing dengan pelaku ekonomi lemah berharap dengan ukuran usaha yang relatif sangat kecil, sehingga tidak memiliki daya saing dengan pelaku ekonomi kuat, apalagi pelaku konglomerat. Sementara itu di pasar tenaga kerja formal, pelaku ekonomi lemah ini tidak bisa menetapkan upah, karena pasar yang dihadapi bersifat monopsoni, atau pembeli tenaga kerja mereka hanya satu, tanpa ada pilihan lain. Dalam bahasa yang kini popular, tak ada nasib yang lain bagi mereka.Dampak dari kondisi pasar tenaga yang monopsoni adalah terjadinya eksploitasi pengusaha atas karyawan sebesar selisih antara upah yang diperoleh dengan produktivitas tenaga kerja karyawan yang notabene adalah pelaku ekonomi lemah. 
Eksistensi pelaku ekonomi lemah dapat bertahan lama pada lingkungan yang menganut patronclient di mana mereka bertindak sebagai client atau pekerja yang dilindungi oleh majikan karena pengabdianya dalam usaha. Namun pada jaman yang semakin kembang ini, iklim usaha yang sangat kompetitif tidak mendukung berlangsungnya kondisi guyup-rukun antara majikan dan bawahan. Hal ini terlihat dari banyakan pelaku ekonomi lemah keluar-masuk pasar tenaga kerja,khususnya dalam kasus pengusaha ekonomi kecil yang kini banyak dikejar.

Di pasar output atau pasar penjualan barang jadi, mereka kebanyakan menjual pada kondisi pasar persaingan sempurna di mana produk yang dijual sangat banyak dan menyebar. Sementara itu kita lihat di pasaran eceran (retail market), terdapat arus komoditas yang dipasok oleh industri konglomerat membanjiri pasaran. Disini ketidakseibangan pasar terjadi karena pada pasar barang yang sama dan harga yang tidakjauh berbeda, konglomerat mampu menjual secara lebih efisien, yaitu menjual lebih banyak, karena itu keuntungan per unit menjadi lebih besar. Disamping itu konglomerat memiliki kondisi penghalang masuk(barner to entry) pada berbagai struktur pasar, Penghalang masuk pasar ini diperoleh dari kemudahan-kemudahan mengdakan diversifikasi produk, disamping permodalan yang kuat pada konglomerat itu sendiri.

Pelaku ekonomi lemah pada dasarnya lemah dalam hal koordinasi secara luas, baik horizontal maupun vertikal, maka secara definitif mereka telah bertindak sebagai konglomerat, sehingga kemungkinan lebih mampu bertahan untuk kompetensi dalam menekan ongkos pada harga jual tertentu. Bila kemampuan ini dapat diusahakan dalam bentuk koperasi-koperasi pemasaran bersama, maka kejayaan pelaku ekonomi lemah adalah suatu hal yang niscaya.

Thailand telah mencoba mengkoordinir para pengusaha ekonomi kecil dalam bisnis pemasaran bersama yang disebut sebagai bazzar. Di bazzar ini para pengusaha ekonomi kecil menggelar dagangnya di suatu tempat tertentu dan waktu tertentu untuk melayani suatu kelompok konsumen tertentu, biasanya para pegawai atau karyawan di halaman kantor atau pabrik selama satu dan dua minggu.Di Jawa kondisi ini terlihat 
misalnya pada saat hari-hari besar tertentu atau pada saat keramaian mengelar Wayang kulit semalam suntuk. Namun untuk sektor modern hal ini boleh ditata belum pernah dicoba, bahkan tampaknya ada kesan untuk dihapuskan.

\section{Pelaksanaan Kesempatan Berusaha}

Pelaksanaan kesempatan berusaha dapat dilakukan lewat mekanisme penjabaran demokrasi ekonomi pada pola alokasi sumberdaya. Pola alokasi sumberdaya pada pengusaha ekonomi kecil masih banyak yang belum terdefinisikan dengan baik, sehingga pelaksanaan pemerataan kesempatan berusahanya juga mengalami banyak hambatan. Salah satu bentuk hambatan pengembangan dalam kesempatan berusaha ini adalah akibat dari persaingan yang ketat antara para pengusaha ekonomi kecil dalam mencapai kondisi ekonomi yang lebih baik.

Kekuatan-kekuatan yang mempengaruhi persaingan tersebut datang dari empat penjuru angin, yaitu dari para pemasok yang sanantiasa menimgkatan kekuatan tawar menawar dalam membeli. Di samping itu persaingan antara perusaha ekonomi kecil juga mendapat ancaman dari masuknya pendatang baru yang potensial, serta ancaman dari adanya atau munculnya produk atau jasa penganti (barang substitusî).

Pemerataan kesempatan berusaha dalam pelaksanaannya mengalami banyak hambatan, karena adanya penghalang masuk (barrier to entry) pada beberapa industri yang telah mapan di pasar. Beberapa penghalang masuk tersebut antara lain : skala ekonomis (economies of scale), adanya diferensiasi produk, sulitnya masuk ke saluran distribusi yang ada, keunggulan biaya dari industri yang telah mapan, dari kebijakan pemerintah juga kadang-kadang merupakan suatu penghalang masuk ke industri.

Skala ekonomis merupakan satu kendala yang berssifat struktural. Skala ekonomis ini terjadi bila sudah industri telah mengembangkan outputnya sedemikian rupa sehingga terjadi efisiensi pada berbagai fungsí bisnisnya, seperti pada fungís penggolahan, pemasaran, riset dan pengembangan, pelayanan distribuís, dan sebagainya. Pada efisiensi yang optimal,maka industri dapat menjual produk. Pada jumlah besar pada harga relatif murah, hal ini menyebabkan pelaku ekonomi lain tidak dapat memasuki 
misalnya pada saat hari-hari besar tertentu atau pada saat keramaian mengelar Wayang

kulit semalam suntuk. Namun untuk sektor modern hal ini boleh ditata belum pernah dicoba, bahkan tampaknya ada kesan untuk dihapuskan.

\section{Pelaksanaan Kesempatan Berusaha}

Pelaksanaan kesempatan berusaha dapat dilakukan lewat mekanisme penjabaran demokrasi ekonomi pada pola alokasi sumberdaya. Pola alokasi sumberdaya pada pengusaha ekonomi kecil masih banyak yang belum terdefinisikan dengan baik, sehingga pelaksanaan pemerataan kesempatan berusahanya juga mengalami banyak hambatan. Salah satu bentuk hambatan pengembangan dalam kesempatan berusaha ini adalah akibat dari persaingan yang ketat antara para pengusaha ekonomi kecil dalam mencapai kondisi ekonomi yang lebih baik.

Kekuatan-kekuatan yang mempengaruhi persaingan tersebut datang dari empat penjuru angin, yaitu dari para pemasok yang sanantiasa menimgkatan kekuatan tawar menawar dalam membeli. Di samping itu persaingan antara perusaha ekonomi kecil juga mendapat ancaman dari masuknya pendatang baru yang potensial, serta ancaman dari adanya atau munculnya produk atau jasa penganti (barang substitusî).

Pemerataan kesempatan berusaha dalam pelaksanaannya mengalami banyak hambatan, karena adanya penghalang masuk (barrier to entry) pada beberapa industri yang telah mapan di pasar. Beberapa penghalang masuk tersebut antara lain : skala ekonomis (economies of scale), adanya diferensiasi produk, sulitnya masuk ke saluran distribusi yang ada, keunggulan biaya dari industri yang telah mapan, dari kebijakan pemerintah juga kadang-kadang merupakan suatu penghalang masuk ke industri.

Skala ekonomis merupakan satu kendala yang berssifat struktural. Skala ekonomis ini terjadi bila sudah industri telah mengembangkan outputnya sedemikian rupa sehingga terjadi efisiensi pada berbagai fungsí bisnisnya, seperti pada fungís penggolahan, pemasaran, riset dan pengembangan, pelayanan distribuís, dan sebagainya. Pada efisiensi yang optimal,maka industri dapat menjual produk. Pada jumlah besar pada harga relatif murah, hal ini menyebabkan pelaku ekonomi lain tidak dapat memasuki 
pasar industri tersebut.

Diferensiai produk juga telah membuat penghalang masuk para pelaku ekonomi kedunia bisnis. Diferensiasi produk yang kini malang melintang di Indonesia adalah berbagai jenis barang dan jasa yang dikelolah oleh para konglomet. Kelebihan konglomet ini adalah bahwa dengan mengadakan integrasi vertikal dan horizontal, baik di pasar input maupun output, mereka dapat mengusahai pasar barang dan jasa secara menyeluruh. Dampak negatif dari konglomerat ini disamping memperburuk usaha pemerataan kesempatan berusaha, juga mempermudah praktek-praktek bisnis yang tidak bermoral, misalnya praktek-praktek merusak harga pasar untuk maksud membunuh pesaing (predatory princing) dengan dukungan produk lain yang sedang berjaya di pasar.

Kebutuhan modal yang besar untuk memulai suatu bisnis, juga merupakan penghalang dari usaha pemeratan perusaha disini hak milik terhadap modal dan faktor produksi lainya menjadi masalah karena pada dirinya di perlukan pembenaran pemiliknya. Bila hak-hak milik diperoleh dari kerja keras, misalnya hak atas barang konsumsi yang diperlukan untuk mempertahankan hidup yang paling azasi, maka hak milik tersebut tek perlu pemerataan kesempatan kerja. Dewasa ini masalah ini hak milik terjadi karena terdapat perbedaan antara kenyataan dan pengharapan atas hak milik suatu masyarakat. Apalagi kenyataan yang ada sesuai dengan pengharapan kepemilikan dalam jangka panjang, maka tidak ada masalah timbul dalam hak milik.atau dengan lain perkataan, masalah hak milik timbul karena kekuatan atas hak milik kekuatan kurang terdefinikasikan dengan jenis. Masalah kuat lemahnya hak atas milik tersebut menjadi masalah politik, karenaitu tergantung pada fenomena politik yang berlaku di negara kita.

\section{Kendala Kesempatan Berusaha}

Kendala berusaha juga kadang-kadang merupakan dampak dari suatu kebijakasanaan pemerintah. Pemerintah dapat membatasi bahkan menutup kemungkinan masuknya industri baru dengan berbagai macam peraturan. Pemerintah juga dapat

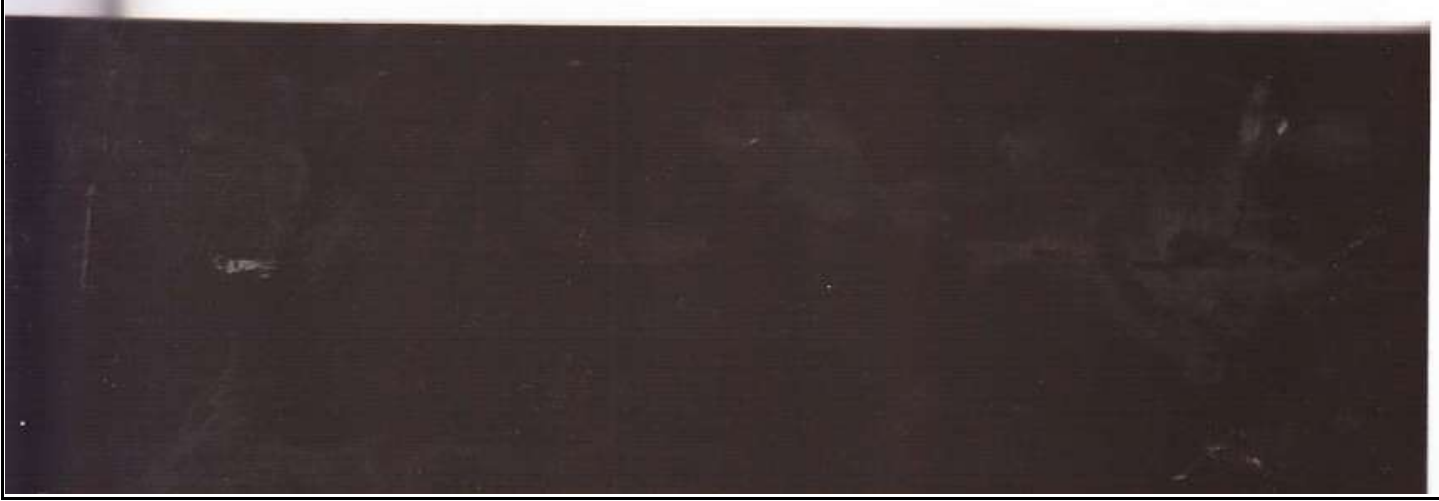


membatasi akses memperoleh dengan cara bahan baku mengurangi pasokan atau menetapkan harga bahan baku lebih mahal.

Pemerataan kesempatan berusaha di Indonesia masih banyak menghadapi kendala yang bersifat struktural. Kendala-kendala tersebut sulit di tembus khususnya oleh para perusaha ekonomi kecil. Pada saat bersamaan pelaku ekonomi kuat masuk pasar dan memperkuat penghalang masuk dengan mengadakan berbagai konglomerasi bisnis yang seharusnya dapat dilakukan oleh para pelaku ekonomi kecil dalam skala kecil-kecilan. Rendahnya kesempatan berusaha ini juga akibat dari tidak seragamnya aliran masuk modal antara pelaku ekonomi kuat dan ekonomi kecil. Modal sangat santer mengalir 'ke pelaku ekonomi kuat, sehingga pelaku ekonomis kecil terhambat masuk ke industri yang bersifat kompetitif.

Pelaksanaan kesempatan berusaha dapat dilakukan lewat meganisme penjabaran demokrasi ekonomi pada pola lokasi sumbernya. Pola lokasi sumbernya pada pelaku ekonomi kecil masih banyak yang belum terdefinisikan dengan banyak, sehingga pelaksanaan pemerataan kesempatan berusahanya juga mengalami banyak hambatan.

Salah satu bentuk hambatan pengambangan dalam kesempatan berusaha ini adalah akibat dari pesaingan yang ketat antara para pelaku ekonomi kecil dalam mencari kondisi ekonomi yang lebih baik. Kekuatan-kekuatan yang mempengaruhi persaingan tersebut datang dari empat penjuru angin, yaitu dari pemasok yang senantiasa meningkatkan kekuatan tawar-menawar dalam menjual; dari para pembeli yang juga ikut peningkatan tawar menawar dalam membeli.Di samping itu persaingan antara pelaku ekonomi kecil juga mendapat ancaman dari masuknya mendatang baru yang potensial, serta ancaman dari adanya atau munculnya produk atau jasa penganti (barang substitusî).

Pemeratan kesempatan dalam pelaksanaannya mengalami hambatan, karena. adanya penghalang masuk (barrier to entry) pada beberapa industri yang telah mapan di pasar. Beberapa penghalang masuk terdapat antara lain:skala ekonomis (economies of scale), adanya diferensiasi produk, tingginya kebutuhan modal yang biaya menganti, sulitnya masuk kesaluran distribusí yang ada keunggulan biaya dari industri yang lelah 
mapan dan kebijakan perintah jugakadang-kadang merupakan suatu penghalang masuk ke industri.

Skala ekonomis merupakan suatu kendala yang bersifat struktural. Skala ckonomis ini terjadi bila suatu industri telah mengembangkan outputnya sedemikian rupa sehingga terjadi efisiensi pada berbagai fungí bisnisnya, seperti pada fungsu pengolahan, pemasaran, riset dan pengembangan, pelayanan, discribuís, dan sebagainya. Pada efiensi yang optimal, maka industri dapat menjual produk pada jumlah besar dengan harga relatif murah. Hal ini menyebabkan pelaku ekonomi lain tidak dapat memasuki pasar industri tersebut.

Diferensiasi produk juga telah membuat penghalang masuk para pelaku ekonomi kedunia bisnis. Diferensiaisi produk yang kini malang melintang di indonesia adalah berbagai jenis barang dan jasa yang dikelolah konglomerat. Kelebihan konglomerat ini adalah bahwa dengan mengadakan integrasi vertikal dan horizontal baik di pasar input maupun output, mereka dapat menguasai pasar barang dan jasa secara menyeluruh. Dampak negatif dari konglomerat ini disamping memperburuk usaha pemeratan kesempatan berusaha, juga mempermudah praktek-praktek bisnis yang tidak bermoral, misalnya praktek-praktek merusak harga pasar untuk maksud membunuh pesaing (poredatory princing) dengan dukungan produk lain sedang berjaya di pasar.

Kebutuhan modal besar untuk memulai suatu bisnis, juga merupakan penghalang dari usaha pemeratan kesempatan berusaha. Di sini hak milik terhadap modal dan faktor produksi lainya menjadi masalah karena pada dirinya diperlukan pembenaran kepemilikannya. Bila hak milik diperoleh dari kerja keras, misalnya hak atas barang konsumsi yang diperlukan untuk mempertahankan hidup yang paling azazi, maka hak milik tersebut tak perlu pemeratan kesempatan kerja. Dewasa ini masalah hak milik terjadi karena terdapat perbedaan antara kenyataan dan pengharapan atas hak milik suatu masyarakat. Apabila kenyataan yang ada sesuai dengan pengharapan kepemilikan dalam jangka panjang, maka tidak ada masalah timbul dalam hak miliki.atau dengan lain perkataan, masalah hak milik timbul karena kekuatan hak milik tersebut kurang

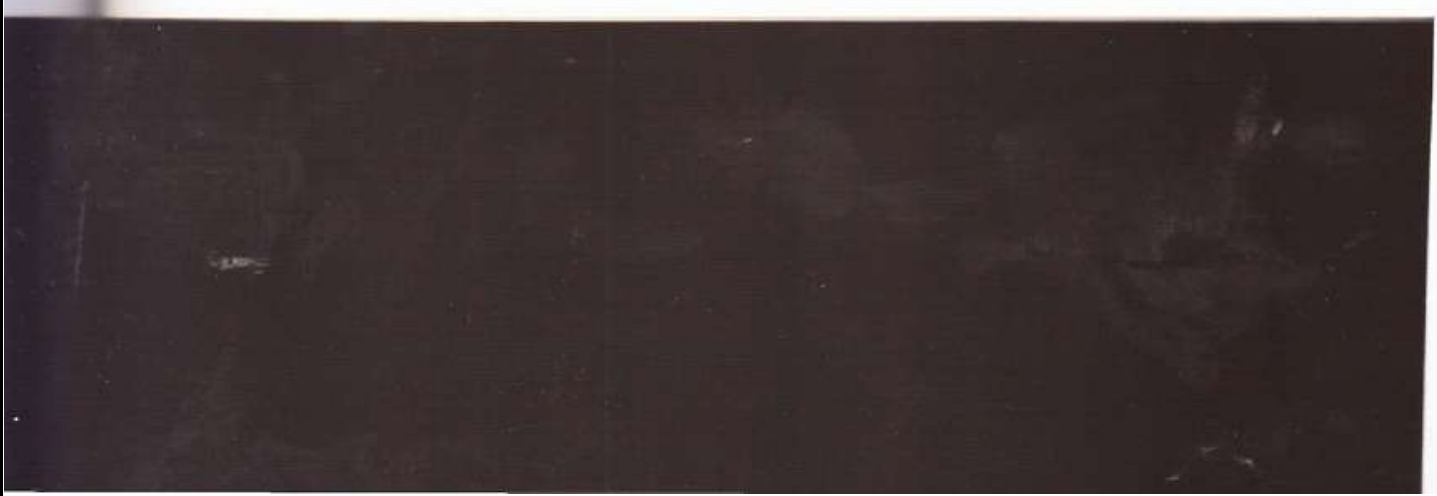


didenfinisikan dengan jelas. Masalah kuat lemahnya hak atas milik tersebut menjadi masalah politik, karena itu tergantung pada fenomena politik yang berlaku di negara kita.

\section{Anatomi Pengusaha Ekonomi Kecil}

Bicara mengenai anatomi pelaku ekonomi lemah dapat digolongkan kedalam pelakunya di pasar input dan pasar output. Dari kedua pasar ini akan diketahui bahwa kedudukan mereka lemah secara struktural, karena itu usaha-usaha kearah perbaikan nasib pelaku ekonomi lemah hanya dapat dilakukan secara struktural dan berjangkan panjang.

Disamping input, pelaku ekonomi lemah hanya bisa menjual jasa dalam bentuk tenaga kerja saja. Mereka tidakmemiliki input lain seperti modal lain lahan pertanian yang cukup, dan tinggat kewiraswataan yang mantap.tenaga kerja yanag dapat mereka sediakan pun sangat homogent dan berjumlah terbatas (unlimeted labour supply). Sehingga upah yang dapat mereka harapkan hanya sebatas pada kebutuhan konsumsi untuk dua orang. Bila jumlah anggota keluarga empat, maka suami istri harus bekerja untuk bisa menutup kebutuhan konsumen. Kondisi struktrural pasar tenaga kerja, baik informal maupun formal pada dasarnya tidak jauh berbeda di pasar informal pelaku ekonomi, berhadapan dengan ukuran yang relatif sangat kecil sehingga tidak memiliki daya saing dengan pelaku ekonomi kuat, apalagi pelaku konglomerat. Sementara itu di pasar tenaga kerja formal, pelaku ekonomi lemah ini tidak bisa menetapkan, karena pasar yang dihadapi bersifat monopsoni, atau pembeli tenaga kerja mereka hanya satu, tampak ada pilihan lain. Dalam bahasa yang kini populer, tak ada masalah lain bagi mereka. Dampak dari kondisi pasar tenaga yang monopsoni adalah terjadinya eksploetasi pengusaha atas karyawan sebesar selisih antara upah yang diperoleh denga produktivitas tenaga kerja karyawan yang notabene adalah pelaku ekonomi rendah.

Eksistensi pelaku ekonomi lemah dapat bertahan lama pada lingkungan yang menganut patroliclient dimana mereka bertindak sebagai client atau pekerja yang dilindungi oleh majikan karena pengambdiannya dalam usaha. Namun pada jaman

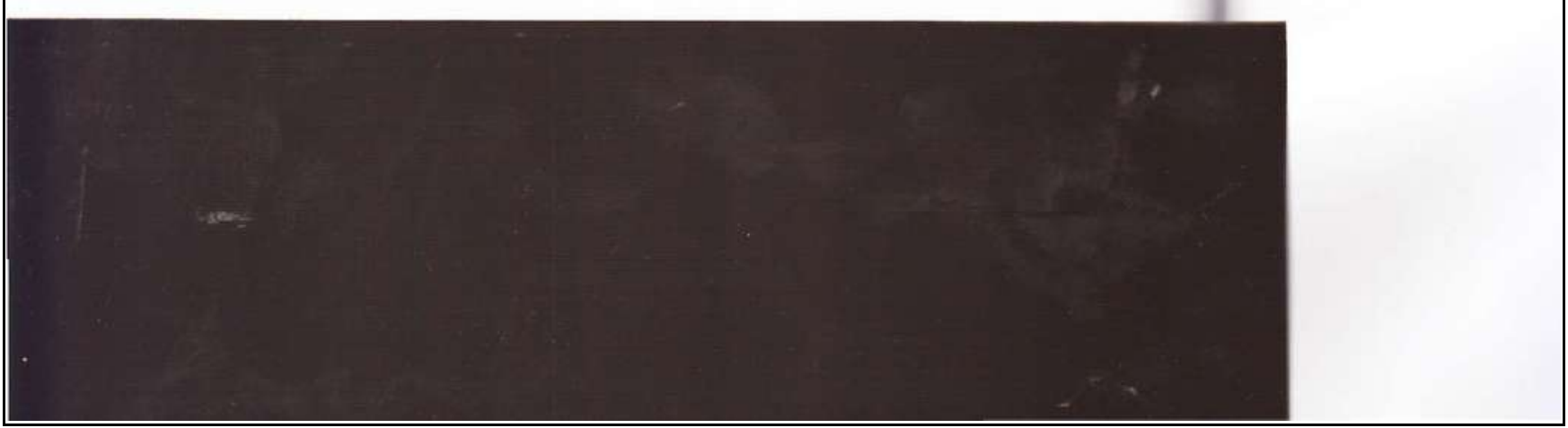


semakin berkembang ini, iklim usaha yang sangat kompetitif tidak mengandung berlakunya kondisi guyub rukun antara majikan dan bawahan. Hal ini terlihat dari banyaknya pelaku ekonomi lemah keluar masuk pasar tenaga kerja, khusunya di tingkat industri pembantu rumah tangga. Kondisi yang terlihatke permukaan ini bahkan sampai muncul di pasar internasional tenaga kerja wanita (TKW) yang banyak tidak kerasan di negeri asing.

Di pasar output atau penjual barang jadi, mereka kebanyakan menjual pada kondisi pasar persaingan sempurna di mana produk yang dijual sangat banyak dan menyebar.Sementara itu kita lihat di pasar eceran (retail market), terdapat aruskomoditas yang dipasok oleh industri konglomerat membanjiri pasaran. Disini ketidakseimbangan pasar terjadi karena pada pasar barang yang sama dan harga yang tidak jauh bebeda, konglomerat mampu menjual secara lebih efisein, yaitu menjual lebih banyak, karena itu keuntungan perunit menjadi lebih besar. Di samping itu konglomerat memiliki kondisi penghalang masuk (barrier to entry) pada berbagai struktur pasar. Penghalang masuk pasar ini diperoleh dari kemudahan-kemudahan mengadakan diversikasi produk, disamping permodalan yang kuat pada konglomerat itu sendiri.

Pelaku ekonomi lemah pada dasarnya lemah dalam koondinasi.Bila mereka dapat melakukan koordinasi secara luas, baik horizontal maupun vertikal, maka secara terdefinisikan mereka telah bertindak sebagai konglomerat, sehingga kemungkinan lebih mampu bertahan untuk berkompetensi dalam menekan ongkos pada harga jual tertentu. Bila kemampuan ini dapat diusahakan dalam bentuk koperasi-koperasi pemasaran bersama, maka kejayaan pelaku ekonomi lemah adalah suatu hal yang niscaya.

Thainland telah mencoba mengkoordinir para PKL dalam bisnis permasaran bersama yang disebut sebagai bazzar. Di bazzar ini para PKL menggelar daganganya di suatu tempat tertentu dan waktu tertentu untuk melayani suatu kelompok konsumen tertentu, biasanya para pegawai atau karyawan di halaman kantor atau pabrik selama satu atau dua minggu. Di Jawa kondisi ini terlihat misalnya pada saat hari-hari besar tertentu atau pada saat keramaian mengelar wayang kulit semalam suntuk. Namun untuk 
sektor modern hal ini boleh dikata belum pernah dicoba, kecuali oleh ibu-ibu rumah tangga secara sporadis.

\section{Kesimpulan}

Peranan komoditas ekspor non migas Indonesia semakin, penting terutama menjelang era tinggal landas, diharapkan komoditas ini dapat menjadi tulang punggung ekspor Indonesia setelah ekspor migas menampakkan pertumbuhan yang semakin menurun, namun demikian,pemasaran ekspor non migas inibanyak menghadapi kendala, terutama kendala dari negara tujuan ekspor berupa penghalang masukbaik tarif maupun non tarif. Dengan berkembanganya persetujuan umum tentang tarif dan perdagangan(GATT), maka liberalisasi perdagangan diberlakukan dengan mengurangi tarif sebanyak mungkin. Namun penghalang non tarif telah banyak menggantinya kebijakan tarif, sehingga pertumbuhan ekspor non migas kita masih banyak menghadapi kendala.

Berbagai usaha dapat dilakukan untuk membuat perdagangan antar negara menjadi lebih matang (fair trade). Salah satu yang dapat dilakukan adalah meningkatkan peranan lembaga-lembaga internasional yang berpihak pada negara-negara berkembang, sehingga kepentingan Indonesia dapat terwakili dan pada saat bersamaan promosi ekspor non migas dapat lebih digencarkan. 


\section{Daftar Pustaka}

Bambang Tri Cahyono,1990, Ekspor Non Migas : Peranan Pemerintah, dalam Harian Sore Wawasan, 3 Mei 1990.

Bambang Tri Cahyon,1990, Demokrasi Ekonomi dan Knglomerat Indonesia : Suatu Tinjauan Era Deregulasi, dalam Pangsa, No.1/4 diterbitkan oleh Himiespa.

Haryono Subyakto dan Bambang Tri Cahyono, 1983, Ekonomi Koperasi, Penerbit Liberty.

Johnson,Galen L., 1986, Research Methodology for Economists Philosophy and Pratice, Penerbit Mcmillan.

Kipnis dan Mayers(Eds) 1985, Economic Justice, Penerbit Rowman \& Allanheld Porter,Michaele.,1989, Strategi Bersaing : Teknik Menganalisis Industri dan Pesaing, diterjamahkan oleh Agus Maulana,Penerbit Erlangga. 


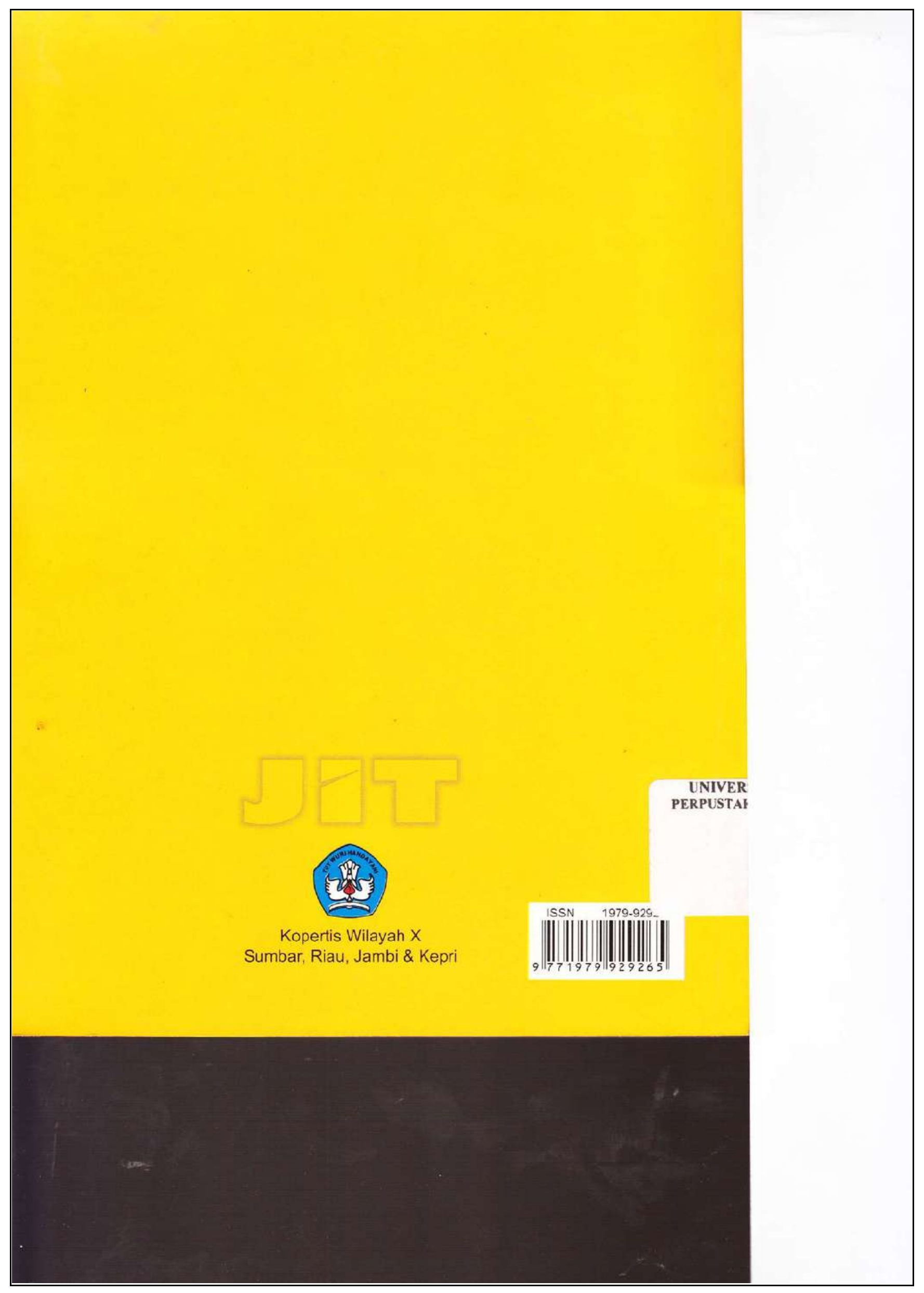




\section{1_jurnal_JIT_APR_2009.pdf}

ORIGINALITY REPORT

$0 \%$

SIMILARITY INDEX
$0 \%$

INTERNET SOURCES
$0 \%$

PUBLICATIONS
$0 \%$

STUDENT PAPERS

1 Srihadiyati Ayu Bestari, M Firdaus, Rohayati Suprihatini, Trias Andati. "Portfolio business to self-financing of research institution (Case study: Research Institute for Tea and Cinchona)", Jurnal Penelitian Teh dan Kina, 2016

Publication

Exclude quotes

On

Exclude bibliography
Exclude matches

Off 